\title{
PELAKSANAAN PERALIHAN HAK ATAS TANAH BERDASARKAN PERJANJIAN PENGIKATAN JUAL BELI DAN KUASA UNTUK MENJUAL YANG DIBUAT OLEH NOTARIS
}

\author{
Bambang Eko Mulyono \\ Dosen Fakultas Hukum Universitas Islam Lamongan.
}

\begin{abstract}
ABSTRAK
Tanah merupakan sumber kekayaan alam yang sangat penting bagi manusia. Dimana untuk mendapatkannya bisa dilakukan dengan berbagai cara, diantaranya jual beli. Penelitian ini bertujuan untuk mengetahui dan menjelaskan : Dasar kewenangan Notaris untuk membuat perjanjian pengikatan jual beli dan kuasa untuk menjual; dan peralihan hak atas tanah berdasarkan kuasa untuk menjual. Jenis penelitian ini menggunakan pendekatan normatif. Pendekatan penelitian bersifat kualitatif, dengan cara menganalisis bahan hukum secara komprehensif yakni bahan hukum primer maupun bahan hukum sekunder yang diperoleh selama melakukan penelitian. Dari penelitian tersebut menunjukkan dasar kewenangan Notaris sebagai pejabat umum yang berwenang untuk membuat akta otentik sebagaimana kewenangan yang diberikan oleh Undang-Undang; dan peralihan hak atas tanah yang dibuat dihadapan Pejabat Pembuat Akta Tanah bisa dilakukan dengan dasar kuasa untuk menjual yang berkaitan dengan perjanjian pendahuluan, yakni perjanjian pengikatan jual beli yang dibuat oleh Notaris.
\end{abstract}

\section{Kata Kunci : Peralihan hak, jual beli, Kuasa untuk menjual.}

\section{Pendahuluan}

Sebagai salah satu faktor penting bagi kehidupan tentu kita tidak bisa mengabaikan keberadaan tanah, dimana Negara Indonesia merupakan negara agraris dengan wilayah yang sangat luas. Seiring dengan semakin pentingnya fungsi tanah bagi kehidupan dan adanya hubungan yang erat tersebut membuat manusia berlomba-lomba untuk menguasai dan memiliki bidang tanah yang diinginkan karena nilai ekonomis bagi segala aspek kehidupan. Sehingga tidak jarang tanah sering menjadi bahan sengketa, terutama dalam hal hak kepemilikan. 
Kenyataan ini menunjukkan bahwa kedudukan dan peranan hak atas tanah dalam masyarakat Indonesia sangatlah penting. Karena pentingnya kedudukan dan peranan tanah maka sering menimbulkan masalah.

Untuk menciptakan kemakmuran dan kesejahteraan rakyat seperti yang diinginkan bangsa Indonesia sebagaimana yang diamahkan dalam pasal 33 ayat 3 Undang-Undang Dasar 1945 yang berbunyi Bumi, air dan kekayaan alam yang terkandung didalamnya dikuasai oleh Negara dan dipergunakan untuk sebesarbesarnya kemakmuran rakyat, maka permasalahan yang berkaitan dengan penggunaan, pemilikan, penguasaaan dan peralihan hak atas tanah memerlukan perhatian yang khusus dalam peraturan perundangan, maka pada tanggal 24 September 1960 keluarlah peraturan perundang-undangan tentang pertanahan, yang dikenal dengan Undang-Undang No. 5 Tahun 1960 tentang Peraturan Dasar PokokPokok Agraria atau yang lebih dikenal dengan Undang-Undang Pokok Agraria (UUPA). Dengan tujuan untuk memberikan kepastian hukum di bidang pertanahan, karena sebelum keluarnya Undang-Undang Pokok Agraria (UUPA) di Indonesia berlaku dua sistem hukum di bidang pertanahan, yaitu hukum tanah yang berdasarkan hukum adat (hak ulayat) dan hukum tanah yang berdasarkan hukum barat yang terdapat dalam BW (Burgerlijk Wetboek/Kitab Undang-Undang Hukum Perdata).
Salah satu cara yang dipergunakan untuk memenuhi kebutuhan akan tanah adalah melalui jual beli. Jual beli bukanlah hal yang baru di masyarakat kita, karena praktek jual beli telah lama dilakukan sejak zaman dahulu. Proses jual beli biasanya dilakukan dengan suatu perjanjian ataupun kesepakatan antara para pihak yang berkepentingan.

Perjanjian jual beli itu sudah dilahirkan pada detik tercapainya "sepakat" mengenai barang dan harga. Begitu kedua pihak sudah setuju tentang barang dan harga, maka lahirlah perjanjian jual beli yang sah. ${ }^{22}$

Jual beli dengan objek hak atas tanah, juga dilakukan dengan perjanjian untuk lebih memberikan kepastian hukum, karena hak atas tanah termasuk objek perjanjian yang secara khusus diatur dalam peraturan perundang-undangan yang berlaku, di mana setiap perbuatan hukum yang menyangkut tentang hak atas tanah terikat atau harus mengikuti ketentuan yang diatur dalam peraturan perundangundangan tersebut. Maksudnya pihak yang akan melakukan perbuatan hukum yang menyangkut tentang hak atas tanah, harus tunduk terhadap aturan hukum yang mengatur atau berkaitan dengan pengaturan tentang hak atas tanah.

Dengan adanya suatu aturan khusus mengenai peralihan hak atas tanah terkadang menimbulkan kesulitan tersendiri bagi masyarakat, terutama bagi masyarakat awam

${ }^{22}$ R. Subekti. Aneka Perjanjian. PT. Citra Aditya Bakti. Bandung. 1995. h. 2. 
yang kurang mengetahui tentang aturan hukum yang berkaitan dengan tanah.

Misalnya dalam suatu transaksi jual beli tanah, oleh kalangan masyarakat awam, dimana jual beli hak atas tanah hanya dilakukan dengan alat bukti selembar kuitansi biasa saja. Pada dasarnya hal tersebut tidak dilarang, akan tetapi bisa menimbulkan suatu permasalahan baru ketika pihak pembeli akan mendaftarkan hak atas tanah yang telah dibeli ataupun di balik nama ke Kantor Pertanahan, karena Kantor Pertanahan akan menolaknya, karena tidak terpenuhinya syarat-syarat pendaftaran tanah.

Semua hak-hak atas tanah wajib didaftarakan kepada kantor pendaftaran tanah oleh pemegangnya untuk menjamin kepastian hak dan merupakan bukti yang kuat terhadap pihak ketiga. Dalam hal ini pemegang hak atas tanah akan mendapatkan suatu tanda bukti hak atas tanah yang terkenal dengan sebutan Sertipikat Tanah. ${ }^{23}$

Pendaftaran tanah sebagai
pembuktian mengenai hak kepemilikan akan suatu bidang tanah perlu dilakukan, sehingga jelas siapa pihak yang mempunyai hak penguasaan dan pemilikan akan bidang tanah tersebut. Hal ini sesuai dengan tujuan dan fungsi dilakukannya pendaftaran tanah sebagaimana diatur dalam Pasal 3 Peraturan Pemerintah Nomor 24 Tahun 1997 tentang Pendaftaran

${ }^{23}$ C.S.T. Kansil. Pengantar Ilmu Hukum dan Tata Hukum Indonesia. Balai Pustaka. Jakarta 1989. h. 321.
Tanah yaitu untuk memberikan kepastian hukum dan perlindungan kepada pemegang hak atas suatu bidang tanah, satuan rumah susun dan hak-hak lain yang terdaftar agar dengan mudah dapat membuktikan dirinya sebagai pemegang hak yang bersangkutan.

Pendaftaran peralihan hak atas tanah perlu dilakukan untuk mendapatkan kepastian hukum, sehingga untuk itu perlu dibuatkan akta peralihan hak guna memenuhi persyaratan pendaftaran tanah. Sebagaimana diatur dalam Peraturan Pemerintah Nomor 24 Tahun 1997 tentang Pendaftaran Tanah dan Peraturan Pemerintah Nomor 37 Tahun 1998 tentang Peraturan Jabatan Pejabat Pembuat Akta Tanah, harus dilakukan dihadapan pejabat yang berwenang, dalam hal ini adalah Pejabat Pembuat Akta Tanah (PPAT), yang daerah kerjanya meliputi daerah dimana tanah tersebut akan dialihkan haknya.

Sebagaimana peraturan mengenai suatu peralihan hak, maka perlu diperhatikan tentang syaratsyarat pembuatan akta peralihan hak tersebut, yakni dipenuhinya syaratsyarat mengenai peralihan hak. Syarat dimaksud bisa mengenai subjek jual beli ataupun objek jual belinya. Namun seandainya syaratsyarat tersebut belum terpenuhi maka penandatanganan akta jual beli belum bisa dilakukan di hadapan Pejabat Pembuat Akta Tanah (PPAT), hingga terpenuhinya semua syarat kelengkapan.

Keadaan ini tentu dirasa kurang menguntungkan bagi para pihak yang mengajukan proses 
peralihan, karena pihak penjual harus menunda penjualan tanahnya sehingga tertunda pula keinginannya untuk mendapatkan uang dari hasil penjualan tersebut. Disamping itu, pihak pembeli juga merasakan hal yang sama dengan tertundanya keinginan untuk mendapatkan hak atas tanah yang akan dibelinya.

Sehingga untuk mengatasi hal tersebut, dan untuk tertib administrasi pertanahan, maka dibuatlah suatu Perjanjian Pengikatan Jual Beli dan Kuasa Untuk Menjual yang dibuat dihadapan Notaris, dimana perjanjian tersebut bisa dipergunakan sebagai salah satu cara untuk mengikat keinginan para pihak. Namun perjanjian pengikatan jual beli hanya sebatas perjanjian bantuan yang merupakan perjanjian pendahuluan yang mendasarkan pada kebebasan berkontrak dan asas-asas perjanjian lainnya, seperti konsensualisme, kekuatan mengikat serta keseimbangan terutama karena belum dapat dilakukan perjanjian yang hendak dituju oleh pada pihak. ${ }^{24}$ Karena suatu sebab sehingga belum terpenuhinya syaratsyarat jual beli, maka untuk proses tertib administrasi pertanahan selanjutnya dilangsungkan dengan akta jual beli yang dibuat oleh oleh Pejabat Pembuat Akta Tanah sebagaimana diatur oleh peraturan perundangan.

\subsection{Rumusan Masalah}

24 Pengurus Pusat Ikatan Notaris Indonesia. 100 Tahun Ikatan Notaris Indonesia, Jati Diri Notaris Indonesia, dulu, sekarang dan di masa datang. PT. Gramedia Pustaka. Jakarta. h. 80
Berdasarkan uraian pada latar belakang masalah diatas, maka dapat diidentifikasi pokok permasalahan yang akan diteliti lebih lanjut yaitu sebagai berikut :

a. Apa dasar kewenangan Notaris untuk membuat Perjanjian Pengikatan Jual Beli dan Kuasa Untuk Menjual?

b. Bagaimanakah proses peralihan hak atas tanah berdasarkan Kuasa Untuk Menjual?

\subsection{Tujuan Penelitian}

Dalam penelitian ini bertujuan untuk :

a. Mengetahui dasar kewenangan Notaris dalam membuat Perjanjian Pengikatan Jual Beli dan Kuasa untuk menjual.

b. Mengetahui Proses peralihan hak atas tanah berdasarkan Kuasa Untuk menjual yang dibuat oleh Notaris.

\subsection{Manfaat Penelitian}

Dalam suatu penelitian sangat diharapkan adanya manfaat dan kegunaan karena nilai suatu penelitian ditentukan oleh besarnya manfaat yang dapat diambil dari penelitian tersebut. Adapun manfaat yang diharapkan penulis dari penelitian ini antara lain :

a. Manfaat Teoritis

1. Hasil penelitian ini diharapkan dapat memberikan sumbangan pemikiran pada bidang hukum terutama yang berkaitan tentang perjanjian pengikatan jual beli.

2. Hasil Penelitian ini dapat dijadikan sebagai rujukan bagi penelitian-penelitian yang sejenis

3. Hasil penelitian ini diharapkan mampu memberikan informasi yang bermanfaat bagi pihakpihak yang memerlukannya.

b. Manfaat Praktis

Hasil penelitian ini diharapkan dapat memberikan sumbangan pemikiran terhadap masyarakat 
tentang kedudukan serta akibat hukum yang berkaitan dengan pelaksanaan dari perjanjian pengikatan jual beli dalam jual beli hak atas tanah.

\section{Metode Penelitian}

Tipe penelitian hukum yang dilakukan adalah yuridis normatif (hukum normatif). Metode penelitian Hukum Normatif adalah suatu prosedur penelitian ilmiah untuk menemukan kebenaran berdasarkan logika keilmuan hukum dari sisi normatifnya.

Oleh karena itu penelitian hukum ini difokuskan untuk mengkaji penelitian hukum tentang kaidah-kaidah atau norma-norma dalam hukum positif, yakni norma hukum yang terkait dengan fungsi Pejabat Pembuat Akta Tanah sebagai pejabat yang berhak membuat akta-akta peralihan hak atas tanah dan Notaris sebagai pejabat umum yang berwenang untuk membuat akta otentik.

Oleh karena tipe penelitian yang digunakan adalah tipe penelitian yuridis normatif, maka pendekatan yang digunakan adalah pendekatan perundang-undangan (statue approach) dilakukan dengan menelaah semua undang-undang dan regulasi yang bersangkut paut dengan isu hukum yang sedang ditangani. ${ }^{25}$

Dalam penelitian ini menggunakan dua bahan hokum, yakni bahan hukum primer dan bahan hukum sekunder. Bahan hukum primer terdiri dari perundang-undangan, catatan-catatan resmi, atau risalah dalam pembuatan perundangundangan dan putusan-putusan hakim, sedangkan bahan hokum

25 Peter Mahmud Marzuki. Penelitian Hukum. Kencana Prenada Media Group. Jakarta. 2011. h. 93. sekunder terdiri dari buku hukum termasuk skripsi, tesis dan disertasi hukum dan jurnal-jurnal hukum, disamping itu juga kamus-kamus hukum dan komentar-komentar atas putusan pengadilan.

\section{Hasil dan Pembahasan}

Hukum Perikatan diatur dalam Buku III BW (Buku III KUH Perdata) yang secara garis besar dibagi atas dua bagian, yaitu pertama, perikatan pada umumnya, baik yang lahir dari perjanjian maupun yang lahir dari undangundang dan yang kedua, adalah perikatan yang lahir dari perjanjianperjanjian tertentu. ${ }^{26}$

Hukum Perjanjian menganut sistem terbuka, artinya hukum perjanjian memberikan kebebasan yang seluas-luasnya kepada masyarakat untuk mengadakan perjanjian yang berisi apa saja, asalkan tidak melanggar ketertiban umum dan kesusilaan. ${ }^{27}$

Perjanjian adalah suatu peristiwa dimana seorang berjanji kepada seorang lain atau dimana dua orang itu saling berjanji untuk melaksanakan sesuatu hal. ${ }^{28}$ Sedangkan pengertian perjanjian dalam Kitab Undang-Undang Hukum Perdata (KUH Perdata) diatur dalam Pasal 1313, berbunyi Suatu perjanjian adalah suatu perbuatan dengan mana satu orang atau lebih mengikatkan dirinya terhadap satu orang lain atau lebih.

${ }^{26}$ Ahmadi Miru \& Sakka Pati.

Hukum Perikatan. Rajawali Pers. Jakarta.

2012. h. 1.

${ }^{27}$ Subekti. Hukum Perjanjian. PT.

Intermasa. Jakarta. 1990. h. 13.

${ }^{28}$ Ibid, h. 1. 
Perjanjian yang sah artinya perjanjian yang memenuhi syarat yang telah ditentukan oleh undangundang, sehingga diakui oleh hukum.

Syarat sahnya perjanjian sebagaimana diatur dalam pasal 1320 Kitab Undang-Undang Hukum Perdata, diperlukan empat syarat, yaitu : sepakat mereka yang mengikatkan dirinya, Kecakapan untuk membuat suatu perikatan, Suatu hal tertentu, Suatu sebab yang halal.

Keempat syarat tersebut merupakan syarat yang mutlak yang harus dipenuhi ketika membuat suatu perjanjian, karena tanpa syarat-syarat tersebut maka perjanjian dapat dianggap tidak pernah ada. Syarat pertama dan kedua (sepakat mereka yang mengikatkan dirinya dan kecakapan untuk membuat suatu perikatan) disebut sebagai syarat subjektif karena berkaitan dengan orangorang atau subjek yang mengadakan perjanjian. Apabila syarat subjektif tidak terpenuhi salah satu atau keduanya, maka perjanjian dapat dituntut pembatalannya atau dibatalkan. Sedangkan dua syarat terakhir (suatu hal tertentu dan suatu sebab yang halal) disebut sebagai syarat objektif, dan apabila syarat objektif tidak terpenuhi maka perjanjian tersebut batal demi hukum.

Dalam membuat suatu
perjanjian yang dibuat
dihadapanpejabat yang berwenang,
perjanjian tersebut akan dituangkan
dalam bentuk akta otentik.

Akta otentik sebagaimana dijelaskan dalam Pasal 1868 Kitab Undang-Undang Hukum Perdata adalah suatu akta yang di dalam bentuk yang ditentukan oleh Undang-undang di buat oleh atau dihadapan pegawai-pegawai umum yang berkuasa untuk itu ditempat dimana akta dibuatnya.

Berdasarkan Pasal 1868 Kitab Undang-Undang Hukum Perdata tersebut di atas dapat dilihat bahwa bentuk dari akta ditentukan oleh Undang-Undang dan harus dibuat oleh atau dihadapan Pegawai yang berwenang. Pegawai yang berwenang yang dimaksud disini antara lain adalah Notaris, hal ini di dasarkan pada Pasal 1 angka 1 Undang-Undang Nomor 1 tahun 2004 tentang Jabatan Notaris yang menyatakan bahwa Notaris adalah Pejabat Umum yang berwenang untuk membuat akta otentik.

Otentisitas suatu akta dapat dikatakan sebagai akta otentik manakala akta tersebut dibuat oleh pejabat yang berwenang. Sebagaimana yang disyaratkan dalam pasal 1868 Kitab UndangUndang Hukum Perdata, suatu akta otentik harus memenuhi syaratsyarat sebagai berikut :

a) Akta tersebut harus dibuat oleh seorang pejabat umum.

b) Akta tesebut harus dibuat dalam bentuk yang ditentukan oleh Undang-Undang.

c) Pejabat umum oleh atau dihadapan siapa akta itu dibuat, harus mempunyai wewenang untuk membuat akta tersebut. Sehingga suatu akta dapat dikatakan otentik bukan karena penetapan Undang-Undang, tetapi karena dibuat oleh/atau dihadapan 
seorang pejabat umum dengan memenuhi syarat-syarat yang ditentukan dalam pasal 1868 Kitab Undang-Undang Hukum Perdata.

Akta otentik merupakan alat pembuktian yang sempurna bagi kedua belah pihak dan ahli warisnya serta sekalian orang yang mendapat hak darinya tentang apa yang dimuat dalam akta tersebut. Akta otentik merupakan bukti yang mengikat yang berarti kebenaran dari hal-hal yang tertulis dalam akta tersebut harus diakui oleh hakim, yaitu akta tersebut dianggap sebagai benar selama kebenarannya itu tidak ada pihak lain yang dapat membuktikan sebaliknya.

Sebagaimana Pasal 1 angka 1 Undang-Undang Nomor 30 Tahun 2004, Tentang Jabatan Notaris, menjelaskan Notaris adalah pejabat umum yang berwenang untuk membuat akta otentik dan kewenangan lainnya sebagaimana dimaksud dalam Undang-Undang ini.

Notaris merupakan pejabat umum yang berwenang dan satusatunya pihak yang mempunyai wewenang untuk membuat suatu akta yang bersifat otentik mengenai semua perbuatan, perjanjian dan ketetapan yang diwajibkan oleh perundang-undangan yang berlaku; atau juga dapat dibuat berdasarkan kepentingan masing-masing pihak yang menghendaki dibuatnya akta otentik. $^{29}$

Dalam suatu proses peralihan hak atas tanah yang dibuat di

29 Frans Satriyo Wicaksono. Panduan Lengkap Membuat Surat-Surat Kontrak. Visi Media. Jakarta. 2008. h. 30. hadapan Pejabat Pembuat Akta tanah (PPAT) sering terkendala berbagai macam persyaratanpersyaratan yang berkaitan dengan tertib administrasi pertanahan yang belum terpenuhi, misalnya Sertipikat hak atas tanah yang masih dalam proses balik nama ataupun masih dalam proses penghapusan hak tanggungan. Sehingga para pihak yang akan melaksanakan peralihan haknya mengalami kendala, dan tidak jarang yang seketika itu pula menginginkan proses jual beli itu terselesaikan.

Namun rumitnya pemenuhan terhadap semua yang berkaitan dengan pelaksanaan jual beli di hadapan Pejabat Pembuat Akta Tanah (PPAT), maka ditemukan suatu terobosan hukum dan hingga kini masih dilakukan dalam praktek jual beli yaitu dibuatnya akta Perjanjian Pengikatan Jual Beli (PPJB), meskipun isinya sudah mengatur tentang jual beli tanah namun formatnya baru sebatas pengikatan jual beli yaitu suatu bentuk perjanjian yang merupakan atau dapat dikatakan sebagai perjanjian pendahuluan.

Perjanjian pengikatan jual beli sebenarnya hampir sama dengan perjanjian pada umumnya. Perjanjian pengikatan jual beli lahir akibat adanya sifat terbuka sebagaimana terkandung dalam Buku III Kitab Undang-Undang Hukum Perdata.

Perjanjian pengikatan jual beli lahir sebagai akibat dari belum terpenuhinya persyaratanpersyaratan sebagaimana ditentukan oleh peraturan perundang-undangan yang berkaitan dengan jual beli hak 
atas tanah, sehingga pada akhirnya akan menghambat penyelesaian transaksi jual beli. Persyaratan dimaksud ada yang lahir karena peraturan perundang-undangan yang ada ataupun timbul karena kesepakatan para pihak yang akan melakukan perjanjian. Pada umumnya persyaratan yang sering timbul adalah persyaratan yang lahir dari kesepakatan para pihak yang akan melakukan transaksi jual beli. Persyaratan tersebut dapat bersifat beragam, misalnya karena belum lunas dibayar seluruh harga jual belinya, atau sertipikat tanah haknya sedang dalam penyelesaian balik nama pada instansi yang berwenang sedangkan calon penjual dan calon pembeli sudah setuju melakukan transaksi jual beli. ${ }^{30}$

Dengan terhambatnya persyaratan tersebut, bisa berakibat pada penolakan oleh Pejabat Pembuat Akta tanah dalam pembuatan akta jual beli. Untuk mengantisipasi permasalahan tersebut maka para pihak dapat membuat suatu perjanjian guna menjaga kesepakatan yang telah terjadi sebelumnya, untuk menjaga agar kesepakatan itu terlaksana dengan baik sementara persyaratan yang diminta dapat terpenuhi, maka para pihak dapat membuat suatu kesepakatan awal dalam suatu perjanjian yang pada akhirnya dikenal dengan perjanjian pengikatan jual beli.

Sebagaimana kedudukan perjanjian pengikatan jual beli sebagai perjanjian bantuan ataupun pendahuluan, maka perjanjian

\footnotetext{
${ }^{30}$ Pengurus Pusat Ikatan Notaris Indonesia. Op. Cit. h. 80.
}

pengikatan jual beli berfungsi untuk memperkuat perjanjian pokok yang akan dilakukan. maka sebagaimana fungsinya, perjanjian pengikatan jual beli dapat digunakan untuk mempertegas perjanjian utamanya, serta menyelesaikan hubungan hukum terhadap hal-hal yang telah disepakati dalam perjanjian pengikatan jual beli apabila telah dilaksanakan seutuhnya.

Kuasa untuk menjual merupakan salah satu bentuk dari kuasa khusus, yang dibuat mengikuti pembuatan perjanjian pengikatan jual beli hak atas tanah dihadapan Notaris.

Pembuatan kuasa untuk menjual itu sendiri dilatar belakangi oleh berbagai hal, diantaranya pemegang hak atas tanah/pemberi kuasa tidak bisa hadir dihadapan pejabat yang berwenang karena dalam keadaan sakit, pemegang hak atas tanah/pemberi kuasa tidak bisa hadir dihadapan pejabat yang berwenang karena tidak berada ditempat sementara waktu.

Kondisi dan keadaan semacam ini akan memunculkan permasalahan ketika akan dibuat akta jual beli karena tidak hadirnya pihak penjual, sehingga perlu disikapi dengan pemberian suatu kuasa untuk menjual guna mempermudah diselenggarakannya proses peralihan hak atas tanah dihadapan pejabat yang berwenang.

Kuasa untuk menjual itu sendiri berisi tentang hal-hal yang diperjanjikan oleh para pihak yang bersifat pelimpahan kekuasaan, diantaranya mengatur mengenai hak dan kewajiban para pihak, apa yang 
harus dilaksanakan dan apa yang tidak boleh dilaksanakan.

Akta jual beli merupakan salah satu syarat pembuktian terjadinya peralihan hak atas tanah, yang didalamnya menyebutkan sumber data yuridis.

Dan kewenangan dalam pembuatan akta peralihan hak atas tanah sebagaimana dijelaskan dalam pasal 1 ayat 1 Peraturan Pemerintah Nomor 24 Tahun 1997 tentang Peraturan Jabatan Pejabat Pembuat Akta Tanah menjelaskan bahwa Pejabat Pembuat Akta Tanah, selanjutnya disebut PPAT adalah pejabat umum yang diberi kewenangan untuk membuat aktaakta otentik mengenai perbuatan hukum tertentu mengenai hak atas tanah atau Hak Milik Atas Satuan Rumah Susun.

Pejabat Pembuat Akta Tanah, sebagaimana tugasnya dalam melaksanakan sebagian kegiatan pendaftaran tanah dengan membuat suatu akta peralihan hak sebagai bukti telah terjadi suatu perbuatan hukum mengenai hak atas tanah yang kemudian dapat dijadikan sebagai dasar untuk pendaftaran perubahan data sebagaimana akibat dari perbuatan hukum.

Namun seiring dengan pemenuhan segala syarat administrasi dalam pembuatan suatu akta peralihan hak dihadapan Pejabat Pembuat Akta Tanah, sering terkendala berbagai macam hal. Sehingga dibuatlah suatu terobosan oleh Notaris untuk menyikapi hal tersebut, dengan dibuatkan suatu perjanjian pendahuluan, yang lebih dikenal dengan sebutan Perjanjian Pengikatan Jual Beli dan Kuasa Untuk Menjual.

Kuasa yang diberikan oleh pihak penjual kepada pihak pembeli biasanya bersifat kuasa yang tidak dapat dicabut kembali dimana kuasa tersebut baru berlaku apabila semua persyaratan yang disepakati dalam perjanjian pengikatan jual beli yang ditetapkan oleh penjual telah dipenuhi oleh pembeli. Keadaan inilah yang kemudian oleh banyak kalangan disebut sebagai kuasa mutlak karena kuasa tersebut tidak dapat dicabut kembali.

Sebagaimana Instruksi Menteri Dalam Negeri Nomor 14 tahun 1982 tentang Larangan Penggunaan Kuasa Mutlak Sebagai Pemindahan Hak Atas Tanah. Dalam instruksi tersebut menyebutkan :

a. Melarang Camat dan Kepala Desa atau Pejabat yang setingkat dengan itu, untuk membuat/menguatkan pembuatan Surat Kuasa Mutlak yang pada hakekatnya merupakan pemindahan hak atas tanah.

b. Kuasa Mutlak yang dimaksud dalam Diktum Pertama adalah kuasa yang didalamnya mengandung unsur tidak dapat ditarik kembali oleh pemberi kuasa;

c. Kuasa Mutlak yang pada hakekatnya merupakan pemindahan hak atas tanah adalah Kuasa Mutlak yang memberikan kewenangan kepada penerima kuasa untuk menguasai dan menggunakan tanahnya serta melakukan segala perbuatan hukum yang menurut hukum dapat dilakukan oleh pemegang haknya.

d. Melarang Pejabat-pejabat Agraria untuk melayani penyelesaian status hak atas tanah yang menggunakan Surat Kuasa Mutlak sebagai bahan pembuktian pemindahan hak atas tanah.

Secara umum pemberian kuasa bukanlah hal yang terlalu dipermasalahkan, hanya saja untuk pemberian kuasa yang dilakukan pada perjanjian pengikatan jual beli dengan terdapatnya kata-kata "tidak 
dapat ditarik kembali” pada pemberian kuasanya maka banyak pihak yang kemudian mengidentikkan hal tesebut dengan pemberian kuasa mutlak sebagaimana yang dilarang oleh Intruksi Menteri Dalam Negeri Nomor 14 Tahun 1982 tentang Larangan Penggunaan Kuasa Mutlak Sebagai Pemindahan Hak Atas Tanah.

\begin{tabular}{llr}
\multicolumn{2}{c}{$\begin{array}{c}\text { Sedangkan } \\
\text { pertimbangan }\end{array}$} & \multicolumn{2}{r}{ sebagaimana } \\
dikeluarkannya
\end{tabular}
larangan penggunaan kuasa mutlak adalah karena penggunaan kuasa mutlak sebagai cara untuk mengadakan pemindahan hak atas tanah, tidak lain adalah suatu cara terselubung karena banyaknya para pihak yang memanfaatkan dan menggunakan kuasa mutlak sebagai alat untuk melakukan penguasaan hak atas tanah padahal secara hukum ia tidak berhak untuk memilikinya, seperti banyaknya warga negara asing yang secara hukum terlarang untuk mempunyai hak milik atas tanah, ternyata secara leluasa dapat memiliki hak atas tanah dengan menggunakan kuasa mutlak.

Kuasa mutlak juga sering dimanfatakan oleh pihak-pihak untuk mencari keuntungan seperti halnya ketika pemerintah akan melakukan sebuah proyek pembangunan di suatu wilayah tertentu yang memakan biaya sampai milyaran rupiah, pihak-pihak yang mengetahui hal tersebut segera melakukan pembebasan tanah yang biasanya dilakukan dengan kuasa mutlak.
Selain itu akibat yang ditimbulkan dengan penggunaan kuasa mutlak tersebut adalah terjadinya penumpukan pemilikan tanah pada seseorang yang jelas bertentangan dengan ketentuan yang terdapat dalam Undang-Undang Nomor 5 Tahun 1960 tentang Peraturan Dasar Pokok-Pokok Agraria (UUPA) yang pada akhirnya juga menghambat tujuan landreform yaitu meratakan kepemilikan tanah bisa tidak tercapai. Disamping menyebabkan banyaknya terdapat tanah yang terbengkalai di pedesaan sebagai akibat pemiliknya ternyata adalah orang yang tinggal di kota yang melakukan pembelian hak dengan kuasa mutlak, walaupun dalam pencatatan desa pemiliknya masih penduduk desa setempat.

\section{Berdasar keterangan tentang unsur dari kuasa mutlak sebagaimana Instruksi Menteri Dalam Negeri Nomor 14 Tahun 1982 tentang larangan penggunaan kuasa mutlak, bisa diartikan kuasa yang dipakai dalam pengikatan jual beli tidak termasuk kedalam kuasa mutlak.}

Hal ini disebabkan karena sebagai perjanjian pendahuluan maka perjanjian pengikatan jual beli menunggu dipenuhinya syaratsyarat untuk sampai pada perjanjian pokoknya, dan pencantuman pemberian kuasa dengan ketentuan tidak dapat ditarik kembali diperlukan untuk melaksanakan jual belinya di hadapan Pejabat Pembuat Akta Tanah (PPAT).

Selain itu, pemberian kuasa dengan ketentuan tidak dapat ditarik kembali yang dipakai dalam 
perjanjian pengikatan jual beli tidak mengandung ketentuan tentang hal yang dilarang sebagaimana diatur dalam diktum Dua butir b Intruksi Menteri Dalam Negeri Nomor 14 Tahun 1982, yaitu kuasa mutlak yang pada hakekatnya merupakan pemindahan hak atas tanah adalah kuasa mutlak yang memberikan kewenangan kepada penerima kuasa untuk menguasai dan menggunakan tanahnya serta melakukan segala perbuatan hukum yang menurut hukum hanya dapat dilakukan oleh pemegang haknya, walaupun kuasanya tidak dapat ditarik kembali.

Pemberian kuasa yang tidak dapat ditarik kembali dalam perjanjian pengikatan jual beli bukanlah termasuk ke dalam kuasa mutlak yang dilarang oleh Intruksi Menteri Dalam Negeri Nomor 14 Tahun 1982 tentang Larangan Penggunaan Kuasa Mutlak Sebagai Pemindahan Hak Atas Tanah, sehingga status hukumnya sah-sah saja untuk dilakukan.

Untuk menjamin kepastian hukum mengenai penguasaan atau peralihan hak atas tanah maka perlu dilaksanakan pendaftaran peralihan hak atas tanah. Dengan dasar perjanjian pengikatan jual beli sebagai perjanjian awal, maka peralihan hak atas tanah bisa segera dibuatkan akta jual beli di hadapan Pejabat Pembuat Akta Tanah (PPAT).

Karena akta PPAT sebagai bukti telah dilaksanakannya suatu perbuatan hukum pemindahan hak atas tanah, maka para pihak yang bersangkutan wajib menghadap langsung untuk melaksanakan penandatanganan akta jual beli.

Terhadap jual beli yang telah dibuatkan perjanjian awalnya berupa perjanjian pengikatan jual beli yang disertai dengan kuasa untuk menjual, cukuplah yang hadir hanya pihak pembeli yang kemudian bertindak selaku penjual berdasarkan kuasa menjual.

Untuk menjamin kepastian hukum mengenai penguasaan atau peralihan hak atas tanah maka perlu dilaksanakan pendaftaran peralihan hak atas tanah. Dengan dasar perjanjian pengikatan jual beli sebagai perjanjian awal, maka peralihan hak atas tanah bisa segera dibuatkan akta jual beli di hadapan Pejabat Pembuat Akta Tanah (PPAT).

Karena akta PPAT sebagai bukti telah dilaksanakannya suatu perbuatan hukum pemindahan hak atas tanah, maka para pihak yang bersangkutan wajib menghadap langsung untuk melaksanakan penandatanganan akta jual beli.

Terhadap jual beli yang telah dibuatkan perjanjian awalnya berupa perjanjian pengikatan jual beli yang disertai dengan kuasa untuk menjual, cukuplah yang hadir hanya pihak pembeli yang kemudian bertindak selaku penjual berdasarkan kuasa menjual.

\section{Kesimpulan}

Perjanjian pengikatan jual beli yang dibuat dihadapan Notaris dalam pelaksanaannya sebagai perjanjian awal sebelum dilaksanakannya pembuatan akta 
jual beli mempunyai kekuatan hukum yang sangat kuat, karena merupakan akta notariil yang bersifat akta otentik. Perjanjian pengikatan jual beli sebagai sarana untuk mengikat keinginan para pihak yang berkepentingan dalam pembuatan akta jual beli namun masih terkendala dengan adanya kekurangan syarat-syarat administratif.

Dalam pembuatan perjanjian pengikatan jual beli biasanya diikuti dengan pemberian kuasa, dimana pemberian kuasa yang lebih dikenal dengan kuasa untuk menjual, dimaksudkan untuk memberikan kuasa kepada pihak pembeli oleh pihak penjual untuk mewakili atas nama pihak penjual seandainya dikemudian hari pihak penjual berhalangan hadir.

Pemberian kuasa untuk menjual sebagai pendamping dari perjanjian pengikatan jual beli bukan termasuk dalam kuasa mutlak yang dilarang oleh Instruksi Menteri Dalam Negeri Nomor 14 Tahun 1982 tentang Larangan Penggunaan Kuasa Mutlak Sebagai Pemindahan Hak Atas Tanah, sehingga kuasa untuk menjual status hukumnya sah untuk dilakukan.

\section{Daftar Pustaka}

R. Subekti. Aneka Perjanjian. PT. Citra Aditya Bakti. Bandung. 1995.

C.S.T. Kansil. Pengantar Ilmu Hukum dan Tata Hukum Indonesia. Balai Pustaka. Jakarta 1989.

Pengurus Pusat Ikatan Notaris Indonesia. 100 Tahun Ikatan
Notaris Indonesia, Jati Diri

Notaris Indonesia, dulu, sekarang dan di masa datang. PT. Gramedia Pustaka. Jakarta.

Peter Mahmud Marzuki. Penelitian Hukum. Kencana Prenada Media Group. Jakarta. 2011.

Ahmadi Miru \& Sakka Pati. Hukum Perikatan. Rajawali Pers. Jakarta. 2012.

Subekti. Hukum Perjanjian. PT. Intermasa. Jakarta. 1990.

Frans Satriyo Wicaksono. Panduan Lengkap Membuat SuratSurat Kontrak. Visi Media. Jakarta. 2008.

\section{Peraturan Perundang-Undangan}

Undang-Undang Dasar 1945;

Kitab Undang-Undang Hukum Perdata (Burgerlijk Wetboek)

Undang-Undang Nomor 5 tahun 1960 tentang Peraturan Dasar PokokPokok Agraria;

Undang-Undang Nomor 30 Tahun 2004 tentang Jabatan Notaris.

Peraturan Pemerintah Nomor 24 tahun 1997 tentang Pendaftaran Tanah.

Peraturan Pemerintah Nomor 37 Tahun 1998 tentang Peraturan Jabatan Pejabat Pembuat Akta Tanah

Peraturan Presiden 10 tahun 2004 tentang Badan Pertanahan Nasional.

Instruksi Menteri Dalam Negeri Nomor 14 tahun 1982 tentang Larangan Penggunaan Kuasa Mutlak Sebagai Pemindahan Hak Atas Tanah. 